\title{
POST POST-TRUTH:
}

\section{EPISTEMOLOGIES OF DISINTEGRATION AND THE PRAXEOLOGY OF TRUTH ${ }^{1}$}

\author{
Bernhard Kleeberg \\ University of Erfurt
}

The madman. - Haven't you heard of that madman who in the bright morning lit a lantern and ran around the marketplace crying incessantly, "I'm looking for God! I'm looking for God!" Since many of those who did not believe in God were standing around together just then, he caused great laughter. Has he been lost, then? asked one. Did he lose his way like a child? asked another. Or is he hiding? Is he afraid of us? Has he gone to sea? Emigrated? Thus they shouted and laughed, one interrupting the other. The madman jumped into their midst and pierced them with his eyes. "Where is God?" he cried; "I'll tell you! We have killed him you and I! We are all his murderers. But how did we do this?" (Nietzsche 2007 [1882]: 119-120)

References to Friedrich Nietzsche's Gay Science have become trendy. Recent diagnoses of the socio-political state of affairs suggest that after God's death truth is next. Just as modern science once dug the grave for

\footnotetext{
1 The concept of a praxeology of truth arose as part of a research initiative established with Marcus Sandl and Rudolf Schlögl in 2009 at the University of Constance. Parts of this article are based on Thomas Lampert's translation of a paper co-authored by the late Robert Suter (†2014) (Kleeberg \& Suter 2014a). For helpful critique I would like to thank Friedrich Cain, Cécile Stehrenberger, Folke Schuppert, and one of the anonymous reviewers of this article.
} 
religion, someone else freshly trenched it for science. To most, the identity of the accused seems clear: it was the postmodernists who dug the grave, even if the American president, the Russian president, and others gave poor truth the critical push that made it fall. But regardless who did it, we were now living in a post-truth era. ${ }^{2}$

Yet, just as Nietzsche misjudged the future of religion, I would like to suggest that diagnoses about the death of truth are utterly wrong. Quite the contrary: we are living in a truth era. A close look at the empirical phenomenon, at when, where, and how truth is being invocated, shows that truth has never been more vigorous and youthful than today. Still, ours seems to be a new culture of truth. What we can observe in the ongoing debates is a proliferation of invocations of truth, vehemently advocated. If at all, this seems to lead towards a multiplication of truth. Therefore, an inquiry into truth should, if it wants to grasp it in all its complexity, start by visiting truth at the point where it actually appears, where it is being addressed or denied, that is, in concrete situations or truth scenes. The praxeology of truth sets out to analyse these scenes, claiming that truth is always embedded in practices within which we decide in the first place what to regard as true or false and what consequences are to be drawn. Thus, truth can switch regimes, that is, it can follow the logic of a religious community, the scientific community, or modern mass communication. And if the procedures and techniques of establishing truth profoundly change in accordance to a new regime, we have to ask whether our understanding of truth, as well as the function of truth itself, change as well.

In the following, I will argue that while we should change our concept of truth along the lines of a praxeology of truth, its function seems to be stable - even though in a different way than might be expected: within the praxeology of truth, truth is regarded as a second-order concept that relates to the observation and judgement of knowledge. Truth - that is, the basic hypothesis - only enters the game if knowledge is being questioned, criticised, or discarded, or, maybe more accurately, if a person or group that possesses knowledge is being questioned or attacked. And in this case - and I will come back to it later - to invoke the truth means to escalate the situation, to differentiate or integrate groups, to ask a subject to commit to the group's cause, to confess his or her devotion: it is a technique of identity politics. With this, the basic premises of a praxeology of truth that can be discussed using the

\footnotetext{
${ }^{2}$ Ralph Keyes was allegedly the first to have spoken of the "post-truth era" in a book title in 2004; a vast amount of similar titles have appeared since 2017 (e.g., Ball 2017; D’Ancona 2017; Davis 2017; Fuller 2018; MacIntyre 2018; McMillan 2017; Wilber 2017).
} 
analytical concepts of the truth scene and the truth figure, as well as referring to identity politics and attention as crucial parameters, are implied. In this respect, the praxeology of truth and classical truth theories differ significantly: (1) truth is situated; (2) truth cannot be analysed along the common oppositions of knowledge and belief, universalism and particularism, science and politics, objectivity and subjectivity, but is closely linked to subjectivity. The plausibility of the hypothesis proposed here - that such correlations are both situation-dependent and central for the understanding of truth - can ironically be shown precisely with those pleas for a return to truth that have added another chapter to the long-smouldering foundational dispute in historiography (Kiesow \& Simon 2000) ${ }^{3}$ and recently even the ongoing political debates: for instance, the "marches for science" advocate the authority of scientific facts, but they advocate scientists as a group as well and they display how science functions as a praxis, with its social, political, institutional, and other dimensions (see Kofman 2018).

\section{/// Yesterday's Truth}

Instead of arguing on the basis of a classical (philosophical) interpretation of truth that does not take in the empirical reality of the ongoing political and epistemological conflicts, the praxeology of truth tries to refine the question of truth on the basis of postmodern theories. It assumes that the invocation of truth results in the integration of social groups that have entered a dispute about the correct interpretation of reality - an interpretation relevant to their identity. In the history and sociology of science, this is a familiar phenomenon: an explicit reference to truth or to the objectivity of knowledge often obscures that we are not dealing with epistemological arguments but rather with a dispute about the identity of the subject, as Karl Mannheim put it, ${ }^{4}$ or the moral economy of a Gefiubls- and Denkeollektiv, which Lorraine Daston (1995) has described: it is a dispute

\footnotetext{
${ }^{3}$ See, for instance, Richard Evans's work (1997), or Hans-Ulrich Wehler's, who argued that the "most profound cause of Foucault's cultivated amoral arm-chair nihilism lies in his epistemology" (1998: 85), which presumes historically variable truth regimes; Egon Flaig's (2007) (neo-)Kantian argument for objective reality is similar. More recently Gottfried Gabriel (2013) has made a more differentiated argument, welcoming the "return of truth" and speaking of the new "secret yearning of the postmodern for the referent."

${ }^{4}$ For Mannheim, the question of truth is the question about the emergence of the specific aspectstructure of thinking from which truth arises, and about the identity of the subject that claims the truth; the plurality of truth could not be epistemologically reduced, since every epistemology only told a story about how itself helped to arrive at the truth (see Mannheim 1964: 235-237, 1965 [1929]: 234-236).
} 
about a whole framework of norms and emotions, in reference to which judgements are made about truth and error, and about the epistemic virtues required within this framework. This includes the constitutive rules of rational argumentation, such as negatability, verifiability, and consistency. Take, for instance, Thomas Kuhn's paradigm change: the decision for a new, alternative paradigm cannot be based on rational arguments, since the epistemological standards, the standards of rationality, are themselves part of the paradigms at stake - they ground the normal-scientific tradition. Key to the implementation of the new paradigm is the emergence of an anomaly incompatible with the dominant paradigm, gaining attention, proliferating, and continuously irritating scholars, until an alternative paradigm that is able to integrate the anomaly arises and a scientific revolution might take place. "Therefore," Kuhn (1996 [1962]: 112) writes, "at times of revolution, when the normal-scientific tradition changes, the scientist's perception of his environment must be re-educated - in some familiar situations he must learn to see a new gestalt." So if the world after a "paradigm-induced gestalt switch" (ibid.: 120) is seen in a fundamentally different way, this is due to an act of re-education - a re-education that changes the scholar's identity, since it changes what counts as normal.

In current political debates, truth is often related to questions of identity as well. It is, for example, linked to an intentional (conspiracy theories) deformation (fake news ${ }^{5}$ ) by the media, or it is employed as a sign of modern enlightened rationality (against creationists, or deniers of climate change or of the dangers of COVID-19). While German historian Jörn Rüsen in an essay on science and truth (2006: 159) argued that interest in truth as an issue of "scientific thought" had significantly dwindled in the face of widespread postmodern scepticism, ${ }^{6}$ the last two years have brought a new urgency to the question, since relativist theories of truth seem to have been adopted by political groups of the far right. As Bruno Latour (2004) warned, there has been a hostile takeover of critical arguments that once served to deconstruct hegemonic (scientistic) ontologies

\footnotetext{
${ }^{5}$ The fake-news in-group seems to have a two-stage conception of truth: it (1) denies the statements of outsiders as not true (in the sense of a negative logic of truth that does not qualify their own statements as true but only the statements of others as untrue); and (2) it believes in a hidden truth in which only insiders can partake. The positive, conspiracist logic of truth aims at an esoteric truth beyond the media apparatus.

6 "Truth is a discursive process guided by criteria that render cultural meaning-formations capable of approval. The sciences are an essential element of this process and the university is a site at which it occurs" (Rüsen 2006: 167).
} 
in the name of truth, now in order to underpin ressentiment. ${ }^{7}$ Yet these positions are seldom met by further advancement of postmodern theory and a reflection of current media technologies - academic discourse frequently links truth to classical truth theories and refers to "the" postmodernist relativisation or even dissipation of truth in power relations, against which truth has to be made strong again. The objection that there cannot be more than one truth, that truth is indivisible and universal, timeless and non-subjective points towards a cognitive dissonance. And it is not surprising that first and foremost scientists and journalists, as key representatives of the attacked truth culture, are calling for a return to the truth as the reference point for a new seriousness in science and politics. Thus, for instance, the historian Werner Paravicini in his Die Wabrheit der Historiker (2010: 10) engages in an emphatic battle against postmodern prophets: "When nothing is real to us anymore, nothing valuable to us anymore, let alone sacred." And in the editorial to a special issue on truth of Aus Politik. und Zeitgeschichte, Anne-Sophie Friedel warns of the political consequences of flexible dealings with truth. We should, she emphasises, engage in "the causes for the loss of authority of facts and its traditional sources - science and journalism - in favor of "felt truths" and return to "one of the most fundamental and oldest questions of philosophy: What is truth?" (Friedel 2017: 3; compare Weingart 2017).

Replicating arguments from the science wars of the 1990s, these voices point out that "postmodern epistemologies" had dissolved the code of "true" and "false" into relativist questions of interpretive authority by treating them solely as the effects of power calculations and rhetorical strategies (e.g., Blackburn 2005, 2007; Changeux 2004; Engel \& Rorty 2007; Frankfurt 2006; Gerhardt 2011; Paravicini 2010; Williams 2004). Paul Boghossian, in Fear of Knowledge: Against Relativism and Constructivism (2006), argues against the idea of the social construction of knowledge that has inspired a postmodern relativism, which, he insists, serves as an epistemological justification for dismissing objective facts, especially in social and political disputes. ${ }^{8}$ In their editorial of Die Rückkehr der Wabrheit, Carsten Dutt and Martial Staub emphasise that this did not mean rehabilitating a naïve truth

\footnotetext{
7 Ava Kofman in her article on Latour as "the Post-Truth Philosopher" (2018) speaks of a "rise not only in anti-scientific thinking," but "reactionary obscurantism." Recently, Latour has himself been criticised for giving up some of his critical perspective (see Giraud \& Aghassi-Isfahani 2020). ${ }^{8}$ In Boghossian's (2006) example, the Lakotas' creation myth of the Buffalo people instead of evolutionary theory. See also the German edition (Boghossian 2013). On the connection between such criticisms and the culturalisation of scientific discourses, see my paper co-authored with Andreas Langenohl (Kleeberg \& Langenohl 2011: 290-291).
} 
concept, but rather a "return to seriousness in dealing with the problems of our knowledge culture that have been set aside by the intellectual matadors of the postmodern anything goes" (2007: 4; transl. T. Lampert). Especially the events of 9/11, Simon Blackburn (2007: 5) argues in the same volume, "have reminded people that there are convictions we must affirm. We need truth, reason, and objectivity, and we need them on our side." Blackburn's analysis is directed against postmodernism as well, which, he argues, had undermined Western rationality by adopting a postcolonial sense of life. This has, he continues, relativised truth, reason, and objectivity, as well as "depth and importance," and disavowed them as cultural constructs tinged by the filters of "class, gender, power, culture, and language."

In this debate we can observe in exemplary fashion what the object of a praxeology of truth can be - for the new seriousness brings into play an old opposition: relativism and subjective arbitrariness versus a social and scientific order grounded in objectivity and truth. The hypostatisation of truth and subjectivity into polar opposites, however, obscures the fact that they mutually condition each other. It is no coincidence that the authors cited above have called for a new stance towards the subject: truth is of fundamental significance, Harry G. Frankfurt argued in his book On Truth, because

[i]ndividuals require truths in order to negotiate their way effectively through the thicket of hazards and opportunities that all people invariably confront in going about their lives. [...] Our success or failure in whatever we undertake, and therefore in life altogether, depends on whether we are guided by truth or whether we proceed in ignorance or on the basis of falsehood. It also depends on what we do with the truth (2006: 26-27).

Thus, if truth - beyond any reference to scientific knowledge - in the first instance guarantees the reduction of complexity, the stability of meaning, and success in practical life, it also introduces epistemic virtues into scholarly discourse, if scholars are obliged to believe the theses that they advocate. In this way a programme directed against life "beyond belief and knowledge" (Flügel-Martinsen 2011) is outlined, an identity programme that involves strengthening certain forms of subjectivity: seriousness,

\footnotetext{
9 Paul Feyerabend's "anything goes" has often falsely been attributed to French philosophers and their deconstructivist theories of language, while it was an expression of identity politics against Western scientific rationalism and capitalism, as Philipp Sarasin (2019) has argued.
} 
truthfulness, steadfastness of belief, honesty, conscientiousness, and conviction about the value and validity of one's own truth. In this way the truth postulates draw the consequences from the older debates about "the end of sincerity" (Knaller 2007; Trilling 1972). The invocation of truth serves to strengthen the self (see Foucault 1997, 2005, 2011); ${ }^{10}$ it promotes trust in one's own decision-making capabilities. Truth contributes to the development of subjective capabilities and moral virtues, which together constitute the condition for the truth capacity of subjects. ${ }^{11}$

Obviously, the commitment to truth already presumes certain subjectivation practices that can vary historically - think only of the ancient parrhesiastes (Foucault 2011: 1-32; Gehring \& Gelhard 2012), the medieval scholastic (Signori \& Rösinger 2014), the modern natural scientist, ${ }^{12}$ or the recent whistleblower or debunker. Accordingly, we can presume that the semantics of truth are set in motion by specific forms of dealing with knowledge (or even with belief). Thus, truth is implicitly inserted into frameworks of knowledge-transmission practices in order to distinguish knowledge from non-knowledge; it is invoked to lock in place or qualify transitory knowledge in situations of dispute or to separate it from pseudoknowledge. It serves as the regulative idea for the motivation of advances in knowledge or as (in)official truth in the exercise of power or the call to subversion. Truth - always dependent on subject positions - appears as a difference effect, marks liminality, or reduces ambiguity, for example, in boundary discourses or situations of (critical) complexity and uncertainty, which may hold not least and indeed precisely for the debates about posttruth.

Still the eminent role of subjectivity is hardly noticed by the proponents of this plea to return to classical truth concepts. Popular German philosopher Markus Gabriel, in his epilogue to the German translation of Boghossian's Fear of Knowledge (2013), notes that the book pursues "a thor-

\footnotetext{
${ }^{10}$ Michel Foucault opposed investigating, as a critique of ideology, "errors, illusions, screen-representations, in short, everything that prevents the formation of true discourses" - instead he argued we should focus on the effects, calculations, and politics of the production of truth discourses themselves (Foucault 1980: 9).

${ }^{11}$ It is probably no coincidence that Blackburn's critique of "postmodern" relativism is connected to concerns about not being taken seriously in engaging for truth and about being declared non compos mentis. Behind this is the ideal of rational autonomous subjects asserting themselves and their truth in disputes (see Blackburn 2007: 8-9, 16-19).

${ }^{12}$ Modern natural scientists of the scientific revolution, for instance, had to buttress the credibility of their scientific observations and knowledge by appearing as "gentleman-scholars" and "Christian virtuosos," as Steven Shapin (1995) has argued.
} 
oughly therapeutic impulse" (Gabriel 2013: 136). ${ }^{13}$ And, in September 2019, Gabriel in his book on "eternal truth" and New Realism outlines a new post-postmodern identity, when he states that

the idea of the progressive [...] has moved over to the world of facts. The progressive is now siding with the facts. Today, we have to stand up for scientific objectivity [...] This is the end of postmodernity. In postmodernity the idea was: to be progressive means to dial down the idea of facts and objective truth. Suddenly, it is the other way round (Gabriel \& Eckoldt 2019: 44).

Yesterday's are tomorrow's epistemologies - according to this reactionary epistemology, post-truth and post-modernity form a pair. ${ }^{14}$ But do classical theories of truth really help us to deal with the effects of new media techniques and their regimes of attention or the post-democratic boom of identity politics? The common denominator for these positions appears to be the invocation of a praxis of dealing with truth, although admittedly conceived neither explicitly nor uniformly as such. What remains unquestioned here is that even on the level of discursive negotiations it is evident that various scenarios, participating actors, communicative practices, and horizons of theoretical reflection repeatedly produce their own forms of what is claimed as truth or what is subject to critique.

In order to be able to describe in more detail these different forms of enacting truth, truth should be investigated from the praxeological perspective in the sense of a situated "doing truth." While truth seems to be meaningful or functional only if addressed as timeless and non-subjective, it is thoroughly interlocked with specific subjects carrying out specific practices in specific situations. And hence it is not simply "the truth" that stands at the centre of this methodological approach. The central focus is rather the correlation of truth with other basic epistemological categories and ideals and with specific scenarios and actors and how these co-

\footnotetext{
${ }_{13}$ Boghossian's (classically analytic) accusation of being "counterintuitive" (2006: 5) itself implies the significance of the subject, while his references to science, schools, and courts of law emphasise the situationality or locational specificity of truth (4). The polemical tone of the treatise makes plausible the consideration that truth or the setting-in-motion of truth semantics can be explained as the effect of specific truth scenes, such as that of the dispute. Regarding his talk of "nonsense," we need only imagine the eminent role it would play if the corresponding positions were presented within a discussion of "postmodern" philosophers or analytic philosophers.

${ }^{14}$ Donna Haraway has pointed out that the current debates denote an important political moment "not to go back to very conventional and very bad epistemologies about how scientific knowledge is put together and why and how it holds" (quoted in Kofman 2018).
} 
produce each other in actu. Or, to state it with reference to philosophical truth theories: if the sciences produce and develop knowledge, truth as a second-order concept relates to the observation and judgement of this knowledge. But it is neither redundant (Moore \& Ramsey 1927), nor a mere confirmation of a proposition in the sense of the performative theory of truth (Strawson 1949), but has a social function. To ask about the truth is to pose the question of power, as we could express it with Michel Foucault, ${ }^{15}$ yet first and foremost it is to ask for the commitment to a group.

\section{/// The Praxeology of Truth: Parameters}

The praxeology of truth that my late colleague Robert Suter and I developed starts with the observation that we always encounter truth in complex social contexts. Whether in respect to scientific facts and hypotheses, to statements or confessions, in reality truth seldom satisfies the ideal demands made on it by philosophical theories. What we see is not simply scientists quarrelling over the correct interpretation of their findings or politicians fighting over the true interpretation of statements or actions; we not only see fact-finders trying to debunk fake news or media experts spinning rumours in order to influence public opinion, we find divulged facts, purchased truths, intricate scientific hypotheses, and confessions made under pressure - to name but a few examples. But even if such "dirty" everyday truths do not fulfil the moral norms tied to "the" truth (such as honesty or truthfulness), these norms are nevertheless effective.

A praxeology of truth that is concerned with the analysis of the processes of constituting truth and the human interactions initiated when truth is being invoked in a given situation cannot - or rather must not - simply presume ideal-typically conceived forms of establishing or negotiating truth, as do philosophers who aim at a universal concept of truth. Instead, it has to focus on interests and technologies that vary according to context, and on the situational irritations and manipulations that codetermine such processes and lead to correspondingly differentiated practices of truth. A respective investigation of doing truth has to pay special attention to what is usually designated as the "ethics of truth," although without any moral prefigurations. Its primary focus revolves around moral

\footnotetext{
15 The analysis of truth regimes does not necessarily imply a specific concept of truth - as has ironically been demonstrated using the example of Foucault: Reiner Ruffing (2008: 53) has shown that Foucault, commonly dispraised as a truth relativist, advances a concept of truth (as a revealing and concealing proceeding) that remains closely tied to Martin Heidegger's.
} 
economies or, more precisely, a political epistemology of truth: the object is not a moral concept of truth, but rather the effects of moral arguments and attitudes on the constitution of that which is ultimately attributed validity as a truth norm.

Where must praxeologies of truth begin if their object is not to be arbitrary? The praxeological approach is guided by problematisations of truth that are evident historically, discursively, or epistemically and that fulfil two functions: they invoke a norm of truth and assert its validity in order at the same time to deplore the variety of deviations from it. In this way the truth norm is repeatedly thematised, analysed, criticised, and relativised. The extent to which the norm is established and whether this is intended at all, whether it is in fact already valid or is supposed to be validated only within this problematisation - all of this is obviously variable and dependent on context. The praxeological analysis of such standardisations is less concerned with an ethical or epistemological evaluation than with the implications that accompany the invoking or questioning, the perverting or deconstructing of truth norms. Which of the respective actions are being taken depends - truth and subjectivity being closely intertwined - on the situation and the particular participants. For this reason, the praxeology of truth is especially interested in the aforementioned "dirty truths." And the concept proposed for the framework in which corresponding negotiations of truth occur is the truth scene. For the actors who concurrently assume the function of transmission we propose the concept of truth figures. With these parameters it will hopefully be possible to describe the composition and formation of truth cultures such as those that have recently arisen amidst new media landscapes.

The concept of the truth scene can serve to emphasise the situational, procedural, and performative moment in the consolidation of truth. It is in such scenes that the exploration, reassurance, or confirmation of truth takes place, as well as the correction or refutation of truth. As empirical phenomena these are encountered primarily following disruptions or accentuations of something self-evident, in situations of learning or dispute, but also with demonstrations of power. Here truth becomes visible as occurrence or manifestation (Badiou 2010: 7-35; Foucault 2014: 1-21) 16 $^{16}$ - through processes of de-flexibilisation, reduction, or rendering unambiguous, or through an act of closure that makes the positioning of sub-

${ }_{16}$ Achim Landwehr (2011) in his critique of Paravicini's Die Wabrbeit der Historiker points out that truth "only becomes necessary as a category when doubts emerge, when cognitive discomfort spreads, and when actions fail." 
jects necessary. In truth scenes, participants can appear as rulers, judges, witnesses, chroniclers, priests, scholars, etc.; they are assigned positions and their actions become observable. In this way distinctions can be made between difference effects and performance effects. The spectrum of difference effects can be divided into those of identification and those of pluralisation, depending on whether the truth is confirmed or challenged, either on the level of truth or of subject positions. Here subject positions designate a typified subjectivity that is always normative in two respects: as the epistemological basis of judgements and as the ethical basis of itself. If the refutation of a truth, for example, accompanies the testing of new truths and subjectivities, the confirmation of a truth consolidates and strengthens the participating subjects in their subjectivity. The fact that truth is at stake in truth scenes also engenders performance effects, which can mean a confirmation, ironisation, critique, displacement, or deconstruction of truth and subject positions. These processes cannot always be traced back to the actions of participants, but also encompass unintended disruption effects - for instance, when an experiment fails, an argument proves unreliable, or a documentary film does not seem authentic. ${ }^{17}$

Following Hans-Georg Gadamer, we can understand a truth scene as a truth game to the extent that it represents a "truth event" requiring seriousness from players: it takes hold of them and completes a movement designed neither for repetition nor for an end (Gadamer 2004 [1975]: 102109). ${ }^{18}$ Truth scenes, however, do not aim at a "universal model of being and knowledge," as Gadamer (ibid.: 483) defines the truth event. Rather, they make historical breaks and continuities visible by comprehending truth as a situational event, in which the play of performance and repetition ensures "iterations" of truth and subjectivity along differences (see Derrida 1982). Nevertheless, a central paradox of invoking "the" truth is also observable in them, as the situational character of truth scenes frequently combines directly with their concomitant definition as "trans-situational": namely, primarily "the one" truth is invoked that is neither temporal, nor spatial, nor tied to particular persons. This claim entails heightened risk since truth assertions can fail. Thus, truth scenes also allow those measures

\footnotetext{
${ }_{17}$ On the side of subjectivity, the issue is above all the relationship between Louis Althusser's subjection and Foucault's subjectivation - the former as the rudimentary form of culturally prefabricated self-identification patterns that activate or form the subject, constitutive for subjectivation processes (see Butler 1997: 83-85; Rose 1996a). In truth scenes, the attitude of subjects towards existing subject positions also becomes visible as the expression of their respective subjectivity.

${ }_{18}$ There are parallels here to Foucault's "games of truth" (jeux de verité; see Foucault 1990: 6, 2014 : 12-15; on Greek tragedy as the ritual manifestation of truth, see: ibid.: 22-92; Ewald \& Waldenfels 1992).
} 
that have been introduced to protect against such contingency to emerge particularly clearly, for example, rituals, prescriptions, and performance restrictions - measures that with Foucault we can understand as procedures of "alethurgy." 19

Truth scenes always also depict observation constellations that require indirect and direct forms of presence and thereby also personify truth in order to move it at the same time into the nexus of proximity and distance (see Schlögl 2008). Frequently such observer constellations are tied to specific locations, depicting, for example, the court of law, the laboratory, or the field, and moreover are also tied to specific (social) practices and rituals (see Gieryn 2006, 2018) ${ }^{20}$ Embedded in overarching truth scenarios, concrete scenes are also framed medially, for instance, in the form of a narrative or script that enables their transmission and adaptation in other locations.

Truth figures in general initially call attention to the fact that the visibility of truth is also secured through figurative dispositifs, whether of the "naked truth" (Blumenberg 2001 [1957]; see Konersmann 2008), the "naïve provincial," or "hard facts." These figurative and metaphorical elements of truth provide evidence in specific contexts, indeed even constitute the actual core of the truth problem and allow epistemology to congeal into a mere praxis effect. Truth figures form, on the one hand, the imaginary of truth; on the other hand, they also depict concrete instructions about how individual or collective subjects could authenticate their truth. Thus, truth scenes draw on notions of subject-related truth capacity and simultaneously put these to the test. This capacity for truth is embodied and mediated by truth figures, which can serve as socio-cultural self-descriptions of the definition of truth standards and truth regimes and thus make truth visible in the nexus of social inclusion and exclusion. Truth figures, for instance, can be considered from the beginning as only conditionally capable of truth, for example, on the basis of their gender, their social status, or limited sen-

\footnotetext{
${ }^{19}$ Foucault (2014: 7) designates alethurgy - which is constitutive for every form of hegemony - as "the manifestation of truth as the set of possible verbal or non-verbal procedures by which one brings to light what is laid down as true as opposed to false, hidden, inexpressible, unforeseeable, or forgotten."

${ }^{20}$ Nicholas Jardine (2000) has proposed "scenes of inquiry" as an analytic parameter that emphasises the local and tacit methods, practices, and techniques of practitioners of science. Though he refers to practices, his notion of "scene" rather denotes specific circumstances, while our concept of the scene is more closely related to theories of performativity and theatricality, stressing the constellations of figures, the role of scripts and those aspects that Erika Fischer-Lichte (1998: 86) draws on to reposition the concept of theatricality: performativity, staging, corporality, and perception (see Butler 1988; Goffman 1956; and critically augmenting the concept, Willems 2009).
} 
sory perceptions. The anthropological dimension of truth is also evident here. Catalogues of the senses that are necessary for the perception of truth can be found: as soon as truth figures are based on sense certainty, they can be analysed as specific figures of perception and attention. Hence the body also determines truth constellations according to the qualities attributed to it - thereby invoking the nexus of knowledge and power (Foucault 1978).

The example of the co-production of truth and subjectivity within the framework of a truth scene shows that connections to very different forms of knowledge are created here and at the same time even correlated. As soon as the subject in the truth production also engages in an objectivation of the self, a field of knowledge opens within which a psychologisation of the subject capable of truth can occur. Often the possibility of such psychologisations is linked to the coupling of truth capacity with the inter-subjective verifiability of subjective truth. If truth is dependent on the logical, methodological, or consensus-based consistency of a subject's statement, it becomes at times indistinguishable from communicative competency; and in referring back to the subject that asserts it, truth acquires at the same time an epistemic basis. The truth of the subject makes this objectifiable in three respects: in respect to the subject's psychological disposition, sociability (intersubjectivity), and communicative competency. What becomes clear under such conditions is not least the failure of truth assertions and self-assertions.

The invocation of truth, however, does not have to use methodological forms of verification. It can also occur in affective forms such as emphasis or enthusiasm, which refer to the problematic of non-knowledge. Belief, intuition, and trust are also truth-constitutive moments since these parameters co-construct truth scenes; as forms of non-knowledge they ground not only epistemic cohesion, but also social cohesion and thereby truth hierarchies. ${ }^{21}$ The process of establishing truth can also lead to inclusions and exclusions, if a witness, for example, is proved to have lied or is depicted in more dynamic figurations or transformations (conversions, revelations, loss of faith, etc.). While figures such as the confessor, or the medium who has a revelation, exist primarily in (religiously) coded truth regimes, there are also figures such as the dissident, the nihilist, and the Copernican, who oppose existing truth regimes with different truth concepts or even reject the necessity of truth at all.

${ }^{21}$ The distinction between knowledge and non-knowledge can also be traced back to difference effects and performance effects in truth scenes. 
Truth figures also provide insight into different temporal concepts of truth, such as progress or salvation history, which have their correspondence in pioneers of truth, believers, or investigators. While truth scenes can thus serve as instruments for the analysis of updated assertions of truth, truth figures address the diachronic dimension, ${ }^{22}$ within which the transmission or shock of truth occurs by embodying their recurring guarantors, critics, or enemies. As soon as truth capacity is linked, for example, to social status, personal integrity, or rhetorical skill, they make truth scenes transparent in regard to historical, social, or medial conditions. Thus, truth figures direct attention to the temporal stabilisation or destabilisation of specific truths and their justification patterns. With the inter-figural relationships in which truth figures usually stand, these can accordingly be traditional contexts. However, inter-figural contexts can also take shape as observation constellations: whether the physiognomist recognises typical similarities or the detective identifies clues, whether the eyewitness grounds the accuracy of his or her testimony in subjective experience, the judge issues a decision, the court reporter criticises its lack of consistency, or the liar is exposed in the course of determining judgement and truth - all of these constitute changing figurative networks, whose continual transformation, establishment, expansion, and reduction should be investigated. ${ }^{23}$

This example in turn bolsters our conceptual distinctions. The practices of specific truth cultures, which are describable through truth scenes and truth figures, can be distinguished as independent fields of investigation from the truth theories within whose framework they are reflected, transcended, or even problematised. But even these point to a practical dimension: since well-formulated truth theories do not emerge in all social fields, we should also assume implicit, praxis-inherent truth theories. In the case of explicit theorisation, a truth theory can also have a practical value itself - in the affirmative sense, for instance, it can guide action as the script of a truth scene, or as a problematisation it can formulate a critique of the predominant ways of truth identification and simultaneously outline alternative truth forms. Truth theory thereby influences the composition of

\footnotetext{
${ }^{22}$ On the diachronic dimension of the truth figure using the example of the prophet, see Sandro Liniger and Robert Suter's paper (2013). On "passing on schemas of conduct" that can serve as scripts for truth scenes, see also Foucault (2011: 208). This in turn requires certain medial and representational formats, such as biographies, anecdotes, examples, and protocols.

${ }^{23}$ For a discussion of examples from photographic evidence in detective work to the practices of truth at court see the contributions to Wabrheit, a special issue of Zeitschrift für Kulturphilosopbie (Kleeberg \& Suter 2014b).
} 
truth scenes and figures and also promotes the transmission and privileging of certain forms of truth.

Taken together, the parameters presented here generate the necessary complexity to do justice to a differentiated field of historical investigation. If the local and situational practices and processes of truth production come into view in truth scenes, this synchronic perspective is expanded through truth figures to include the historical, social, and medial presuppositions of such scenes. This historical depth dimension opens the possibility of a (self-reflective) universalisation or relativisation of exemplary scenes and figures in the form of theories. If truth scenes, figures, and theories mutually presume each other, then we propose that they also be analysed in relation to one another in order to utilise their mutual-irritation potential: for instance, invoking scenes and figures (in a relativising way) in connection with statements about the validity of truth theories; countering the question of practices with the function of theories; or questioning the situational analysis of truth scenes by referring to the continuity of truth figures. In this way, a series of questions comes into focus that until now could not even have been raised from this perspective: what are the effects of an invocation of truth? What demands does it generate on the truth capacity of participating actors? What forms of disturbance, irritation, and refutation is truth subjected to and to what extent do these in turn contribute to the establishment of truth? What kind of scenarios set in motion truth semantics and with them specific figurations of actors?

These coordinates stake out a broad field of research, which can then be delimited by focusing on the concrete processes of constituting truth in specific truth scenes, without, however, losing sight of the question of how truth can be reclaimed as the object of interdisciplinary reflection in the humanities. Whereas the manifesto character of the pleas for a return to truth cited at the beginning of this article included bracketing one's own historical presuppositions - in regard to the orienting function of truth, for instance, the philosophical tradition of pragmatism - we propose investigating the formation of certain truth scenes, truth figures, and thereby also truth theories in situ in order to develop a critical historical praxeology of establishing and dismantling truth. Points of connection emerge especially through those praxeological concepts of an ethnographic history and sociology of knowledge and science (Knorr-Cetina 2002; Latour 2018; Latour \& Woolgar 1986; Pickering 1992) ${ }^{24}$ which in the framework of a pragmatic realism - in connection, for example, with Charles S. Peirce,

\footnotetext{
${ }^{24}$ On praxeology as a general sociological approach, see the work of Robert Schmidt (2012).
} 
William James, and James Dewey -emphasise the unfinished, the underdetermined, and the vague dimensions of knowledge production, the situational, the performative, and the procedural dimensions: objects, facts, theories, ideals, and practices are constituted in specific situations in relation to each other; their epistemic status and their active or passive roles are altered in the "dance of agencies" during the "mangle of practice," as Andy Pickering (1995; Pickering \& Guzik 2008; see Haraway 1988, 2008) has called it, in which they come into focus primarily through differences (see Rheinberger 1997, 2001). Together they determine the phenomenon of validity. Thus, the codification of knowledge occurs for the most part only retrospectively before a backdrop of successful processes of "cleansing" objects and homogenising practices (Bachelard 1984; Latour 1994, 2007; Law 2008; Pickering 2009). This access to the co-evolution of knowledge and objects in practice or to the symmetrical "co-production" of nature and society (Latour 1992: 287) can be related in useful ways to the production, homogenisation, stabilisation, and deconstruction of truth.

\section{/// Mediality and Truth as a Social Operator}

With these remarks on a praxeology of truth, let me now come back to the current discussions on post-truth and hint at some of the possible outcomes of this analytical approach. Do we observe specific forms of subjectivation in the ongoing debates? What kind of truth scenes and truth figures can be found? And what does this tell us about a possible change of our culture of truth?

In search for truth in the current media landscapes, we might start with a look at the internet. If you google "truth 2.0," what you get is a hiphop homepage and an EU-sponsored project on citizen science, in which six "citizen observatories" from Europe and Africa provide data about their local environment. ${ }^{25}$ If you try the German "Wahrheit 2.0," amongst the first hits is a soap opera and a Facebook site presenting a (not-at-all surprising) mixture of media bashing, critique of capitalism, anti-Semitic conspiracy theory, official Russian propaganda, and advertisement for natural cosmetics. ${ }^{26}$ Both the English and the German web pages show in their own impressive way - and this would probably become even more obvious in the case of social media - that the regimes of truth we know have shifted,

${ }^{25}$ Ground Truth 2.0, https://gt20.eu/about/about-gt-2-0/, accessed 7.05.2020.

${ }^{26}$ Wahrheit 2.0, Facebook, https://www.facebook.com/pg/Wahrheit-20-280505102133835/ posts/?ref=page_internal, accessed 7.05.2020. 
or are maybe even disappearing (see Harsin 2015), ${ }^{27}$ and that we cannot get hold of "the truth" by means of conventional instruments and truth theories. Besides the delegitimisation of modern truth figures such as the scientist or the (investigative) journalist, we observe a decentralisation and multiplication of communication channels, with a previously unknown plethora of statements containing truth claims which by reason of their sheer quantity alone cannot be checked using traditional verification practices. This truth 2.0 - the "big data truth" - is more related to algorithms of attention than to familiar verification practices.

In an age of ever-simplified access to information, with Twitter, Facebook, Google, and others as the most prominent platforms used, scientific facts and what are presented as such are even more likely to follow the code of information/non-information that, according to Niklas Luhmann, already characterised the system of the classical mass media. The main feature of information lies in its relation to time, as he put it: "Information cannot be repeated; as soon as it becomes an event, it becomes noninformation. A news item run twice might still have its meaning, but it loses its information value" (Luhmann 2000: 19-20). Used as a code value, this meant the system is

constantly and inevitably transforming information into non-information. The crossing of the boundary from value to opposing value occurs automatically with the very autopoiesis of the system. The system is constantly feeding its own output, that is, knowledge of certain facts, back into the system on the negative side of the code, as non-information; and in doing so it forces itself constantly to provide new information. In other words, the system makes itself obsolete (ibid.).

News, that is, information, is being produced by - among other things - surprise, conflicts, quantity, local relevance, norm violations, scandals, and so forth (ibid.: 28ff.). These Luhmannian selectors directly relate to truth scenes: as a machine of escalation, truth leads to conflicts; and the repudiation of information that corresponds to the norms of a truth regime is able to generate attention as it might be understood to be scandalous (think of Kellyanne Conway's comment on the number of attendees at the inaugural speech of the new American president in 2017). And, most

${ }^{27}$ Michael Seemann (2017) speaks of the "deregulation of the truth market"; compare Bernhard Pörksen's article (2018) and Thari Jungen's contribution to this volume. 
importantly, if social media and the internet spread and circulate information, news value can be reassigned to them by branding them as true or false. A truth scene is opened up - a game about fake news, often automatically self-enforcing due to algorithmic feedback loops. This dance around true and false in itself generates attention and entails economic effects, as communication theorist Jayson Harsin has put it. It goes hand in hand with the relatively new practice of fact-checking and the truth figure of the fact checker or debunker, who sometimes works individually, sometimes as part of an organised "real time rumor tracker." ${ }^{28}$ And interestingly, this figure and its practice manifest the correspondence theory of truth as a basic norm of the truth regime that has come under attack.

Harsin's argument concerns media techniques; it aims at the fragmentation of truth as an effect of the multiplication of communication channels and the end of hegemonial truth regimes in the age of mass media. I would like to substantiate this diagnosis from a more sociological perspective and argue that while the multiplication of communication channels has indeed had a damaging effect on traditional truth regimes like that of academia, truth has not been fragmented, but subjectified and multiplied as an effect of social fragmentation and the disintegration of overarching international institutions and organisations. The self-assertion and stabilisation of small communities, specifically via social media, is facilitated by means of a joint drawing of boundaries between true and false. This process of recommunalisation is mirrored in the current crisis of the political, which, powered by the development of digital media, relocates political debates to autonomous fractions of the general public, as sociologist Andreas Reckwitz (2017: 434) argues. As a consequence, not only has the "universal" disappeared from politics, but socially, culturally, and politically shared norms as well: "shared, reciprocal forms of appreciation, shared systems of cultural values and forms of communication and normative frames of the society as a whole" (ibid.: 437; my transl.). Since the self-assertion and stabilisation of communities with their respective identities (especially via social media) can be promoted by drawing borders between true and false, the invocation of truth would thus be a cause and effect of social disintegration at once. Accordingly, the "death of the social," as Nikolas Rose (1996b) termed it, entails the crisis of universal epistemological norms and thus not the death but the vitalisation of the praxis of invocating truth.

If this analysis is true and the new cultures of truth are an effect of social fragmentation as well as of algorithmic attention economies, it might

${ }^{28}$ Emergent, http://www.emergent.info/about, accessed 7.05.2020. 
explain the emergence of a number of relatively young truth figures, like the PR specialist, the spin-doctor, the troll, the fact finder, or the science communicator. Their expertise points to a shift to truth regimes centred on attention and emotions, which are easily manipulated following economic or political agendas. ${ }^{29}$ Adding to this, the idea of a reciprocal entanglement of truth and subjectivity, as the starting point for a praxeology of truth, can be helpful in another way: it uncovers a novel meaning of authenticity as a form of subjectified truth. This helps to explain the recent phenomenon that the exposure of a liar obviously does not entail the consequence that people turn away from him. Here, an old truth practice - to "live in truth" like the faithful or the parrhesiastes - resurfaces, within which truth and subjectivity merge in a form of authenticity. In the face of a transformation of truth regimes, its truth figures, and the media they use, a truth thus embodied can gain ground, as can be studied from the American type specimen of post-democracy. The writer Dave Eggers (2020) recently described his president accordingly: "To his followers, a spontaneous lie is better than a rehearsed truth. [...] They perceive this as refreshing and somehow more honest" (see Umbach \& Humphrey 2018: ch. 4).

Just as truth entails subjectivation, a radical subjectivation like this means that truth pops up in a specific scene - that of staged authenticity. A staging that sociologist Ingolfur Blühdorn (2013; see Reckwitz 2017: 435) has accounted for as the core of the theatrical performance of the political in our late modern simulative democracy. According to the ideals of our "culture of authenticity," as Charles Taylor (1995) termed it in The Malaise of Modernity, the moral code of remaining true to oneself means to articulate one's own supposed originality in the face of instrumental self-reference and social pressure in particular - even if this kind of selffulfilment tips over into narcissism or occurs as an intentional violation of moral codes. And it is this violation - whether in the form of racist or sexist remarks, or as a denial of scientific facts - that generates the emotions and attention necessary to integrate groups and stabilise their identity. Truth as this example makes especially clear - should be rescued from the neat and clean realm of philosophical epistemology and be analysed as the phenomenon of our dirty reality that it very effectively is: a social operator. With a praxeology of truth providing the analytical instruments to do so, one consequence might be to avoid truth scenes that trigger epistemological

29 The Cambridge Analytica scandal, for instance, proved that data is not only collected and aggregated, but also used and misused to make money; see The Cambridge Analytica Files, The Guardian, https://www.theguardian.com/news/series/cambridge-analytica-files, accessed 29.05.2020. 
and political tribalisation, and instead to implement common practices of situated problem-solving or other political strategies that are more downto-earth.

Bibliography:

/// Bachelard G. 1984. The New Scientific Spirit, transl. Arthur Goldhammer, Beacon Press.

/// Badiou A. 2010. "Die gegenwärtige Welt und das Begehren der Philosophie," [in:] Politik der Wabrheit, eds. A. Badiou, J. Rancière, Turia und Kant, pp. 7-35.

/// Ball J. 2017. Post-Truth: How Bullshit Conquered the World, Biteback Publishing.

/// Blackburn S. 2005. Truth: A Guide for the Perplexed, Allen Lane.

/// Blackburn S. 2007. "Kehrt die Wahrheit tatsächlich zurück?," Zeitschrift für Ideengeschichte, vol. 1(3), pp. 5-20, https://doi.org/10.17104/1863-89372007-3-5.

/// Blühdorn I. 2013. Simulative Demokratie. Neue Politik nach der postdemokratischen Wende, Suhrkamp.

/// Blumenberg H. 2001 [1957]. "Licht als Metapher der Wahrheit. Im Vorfeld der philosophischen Begriffsbildung," [in:] Ästhetische und metaphorologische Schriften, ed. A. Haverkamp, Suhrkamp, pp. 139-171.

/// Boghossian P. 2006. Fear of Knowledge: Against Relativism and Constructivism, Oxford University Press, https://doi.org/10.1093/acprof:o so/9780199287185.003.0006

/// Boghossian P. 2013. Angst vor der Wahrheit: Ein Plädoyer gegen Relativismus und Konstruktivismus, transl. J. Rometsch, M. Gabriel, Suhrkamp.

/// Butler J. 1988. "Performative Acts and Gender Constitution: An Essay in Phenomenology and Feminist Theory," [in:] Writing on the Body: Female Embodiment and Feminist Theory, eds. K. Conboy, N. Medina, S. Stanbury, Columbia University Press, pp. 401-417, https://doi.org/10.2307/3207893.

/// Butler J. 1997. The Psychic Life of Power: Theories in Subjection, Stanford University Press. 
/// Changeux J. 2004. The Physiology of Truth: Neuroscience and Human Knowledge, transl. M. DeBevoise, Belknap Press.

/// D'Ancona M. 2017. Post Truth: The New War on Truth and How to Fight Back, Ebury Press.

/// Daston L. 1995. "The Moral Economy of Science," Osiris, vol. 2(10): Constructing Knowledge in the History of Science, pp. 2-24, https://doi. org/10.1086/368740.

/// Davis E. 2017. Post Truth: Why We Have Reached Peak Bullshit and What We Can Do About It, Little, Brown.

/// Derrida J. 1982. "Signature Event Context," [in:] J. Derrida, Margins of Philosophy, transl. A. Bass, University of Chicago Press, pp. 307-330.

/// Dutt C., Staub M., eds. 2007. Zeitschrift für Ideengeschichte, vol. 1(3): Die Rückekehr der Wabrbeit, https://doi.org/10.17104/1863-8937-2007-3.

/// Eggers D. 2020. “Dave Eggers über Wahnsinn,” Süddeutsche Zeitung, vol. 118(23/24.5), p. 52.

/// Engel P., Rorty R. 2007. What's the Use of Truth?, Columbia University Press.

/// Evans R. 1997. In Defense of History, Granta.

/// Ewald F., Waldenfels B. 1992. Spiele der Wabrbeit: Michel Foucaults Denken, Suhrkamp.

/// Fischer-Lichte E. 1998. "Inszenierung und Theatralität," [in:] Inszenierungsgesellschaft: Ein einfübrendes Handbuch, eds. M. Jurga, H. Willems, Westdeutscher Verlag, pp. 81-90, https://doi.org/10.1007/978-3-322-897978_3.

/// Flaig E. 2007. "Ohne Wahrheit keine Wissenschaft: Überlegung zur Wendung nach den Wenden," [in:] Wabre Geschichte-Geschichte als Ware: Die Verantwortung der historischen Forschung für Wissenschaft und Gesellschaft, eds. C. Kühberger, C. Lübke, T. Terberger, Leidorf, pp. 49-80.

/// Flügel-Martinsen O. 2011. Jenseits von Glauben und Wissen: Philosophischer Versuch über das Leben in der Moderne, transcript.

/// Foucault M. 1978. The History of Sexuality: Volume 1: An Introduction, transl. R. Hurley, Pantheon. 
/// Foucault M. 1980. “The History of Sexuality: Interview," Oxford Literary Review, vol. 4(2), pp. 3-14.

/// Foucault M. 1990. The Use of Pleasure: The History of Sexuality, vol. 2, transl. R. Hurley, Vintage.

/// Foucault M. 1997. Ethics: Subjectivity and Truth: The Essential Works of Foucault, 1954-1984, vol. 1, ed. P. Rabinow, Penguin.

/// Foucault M. 2006. The Hermenentics of the Subject: Lectures at the Collège de France, 1981-1982, transl. G. Burchell, ed. F. Gros, Picador.

/// Foucault M. 2011. The Courage of the Truth (The Government of Self and Others II): Lectures at the Collège de France, 1983-1984, transl. G. Burchell, ed. F. Gros, Palgrave.

/// Foucault M. 2014. On the Government of the Living: Lectures at the Collège de France, 1979-1980 and Oedipal Knowledge, transl. G. Burchell, ed. M. Senellart, Palgrave.

/// Frankfurt H. 2006. On Truth, Knopf.

/// Friedel A.-S. 2017. "Editorial," Aus Politik und Zeitgeschichte, vol. 67(13), p. 3, https://www.bpb.de/apuz/245211/editorial, accessed 29.05.2020.

/// Fuller S. 2018. Post-Truth: Knowledge as a Power Game, Anthem Press, https://doi.org/10.2307/j.ctvgd30v.

/// Gabriel G. 2013. "Fakten oder Fiktionen? Zum Erkenntniswert der Geschichte," Historische Zeitschrift, vol. 297, pp. 1-26, https://doi.org/10.1524/ hzhz.2013.0305.

/// Gabriel M. 2013. "Nachwort," [in:] P. Boghossian, Angst vor der Wabrheit: Ein Plädoyer gegen Relativismus und Konstruktivismus, transl. J. Rometsch, M. Gabriel, Suhrkamp, pp. 135-156.

/// Gabriel M., Eckoldt M. 2019. Die ewige Wahrheit und der Neue Realismus: Gespräche über (fast) alles, was der Fall ist, Carl-Auer Verlag.

/// Gadamer H. 2004 [1975]. Truth and Method, 2nd rev. ed., transl. rev. J. Weinheimer, D. Marshall, Continuum.

/// Gehring P., Gelhard A., eds. 2012. Parrhesia: Foucault und der Mut zur Wabrheit, Diaphanes.

/// Gerhardt V. 2011. "Über Wahrheit und Lüge in der Politik," Merkur, vol. 744, pp. 393-402. 
/// Gieryn T. 2006. "City as Truth-Spot: Laboratories and Field-Sites in Urban Studies," Social Studies of Science, vol. 36(1), pp. 5-38, https://doi. org $/ 10.1177 / 0306312705054526$.

/// Gieryn T. 2018. Truth Spots: How Places Make People Believe, University of Chicago Press.

/// Giraud E., Aghassi-Isfahani S.-N. 2020. "Post-Truths, Common Worlds, and Critical Politics: Critiquing Bruno Latour's Renewed Critique of Critique," Cultural Politics, vol. 16(1), pp. 1-13, https://doi. org/10.1215/17432197-8017200.

/// Goffman E. 1956. The Presentation of the Self in Everyday Life, University of Edinburgh.

/// Haraway D. 1988. "Situated Knowledges: The Science Question in Feminism and the Privilege of Partial Perspective," Feminist Studies, vol. 14(3), pp. 575-599, https://doi.org/10.2307/3178066.

/// Haraway D. 2008. When Species Meet, University of Minnesota Press.

/// Harsin J. 2015. "Regimes of Posttruth, Postpolitics, and Attention Economies," Communication, Culture \& Critique, vol. 8(2), pp. 327-333, https://doi.org/10.1111/cccr.12097.

/// Jardine N. 2000 [1991]. The Scenes of Inquiry: On the Reality of Questions in the Sciences, Oxford University Press.

/// Keyes R. 2004. The Post-Truth Era: Dishonesty and Deception in Contemporary Life, St. Martin's Press.

/// Kiesow R., Simon D., eds. 2000. Auf der Suche nach der verlorenen Wabrheit: Zum Grundlagenstreit in der Geschichtswissenschaft, Campus.

/// Kleeberg B., Langenohl A. 2011. "Kulturalisierung, Dekulturalisierung," Zeitschrift für Kulturphilosophie, vol. 2, pp. 281-302, https://doi. org/10.28937/1000106587.

/// Kleeberg B., Suter R. 2014a. “'Doing Truth'. Bausteine einer Praxeologie der Wahrheit," Zeitschrift für Kulturphilosophie, vol. 8(2), pp. 211-226, https://doi.org/10.28937/1000106675.

/// Kleeberg B., Suter R., eds. 2014b. Zeitschrift für Kulturphilosophie, vol. 8(2): Wabrheit. 
/// Knaller S. 2007. Ein Wort aus der Fremde: Geschichte und Theorie des Begriffs Authentizität, Winter.

/// Knorr-Cetina K. 2002. Die Fabrikation von Erkenntnis: Zur Anthropologie der Naturwissenschaft, Suhrkamp.

/// Kofman A. 2018. "Bruno Latour, the Post-Truth Philosopher, Mounts a Defence of Science," New York Times Magazine, 25.10.2018, https://www. nytimes.com/2018/10/25/magazine/bruno-latour-post-truth-philosopher-science.html, accessed 29.05.2020.

/// Konersmann R. 2008. "Implikationen der nackten Wahrheit," Scholion: Bulletin, vol. 5, pp. 21-55.

/// Kuhn T. 1996 [1962]. The Structure of Scientific Revolutions, 3rd ed., University of Chicago Press.

/// Landwehr A. 2011. "W. Paravicini: Die Wabrheit des Historikers," http://hsozkult.geschichte.hu-berlin.de/rezensionen/2011-2-011, accessed 7.05.2020.

/// Latour B. 1992. "One More Turn after the Social Turn," [in:] The Social Dimension of Science, ed. E. McMullin, University of Notre Dame Press, pp. 272-294.

/// Latour B. 1994. We Have Never Been Modern, transl. C. Porter, Harvard University Press.

/// Latour B. 2004. "Why Has Critique Run Out of Steam? From Matters of Fact to Matters of Concern," Critical Inquiry, vol. 30(2), pp. 225-248, https://doi.org/10.1086/421123.

/// Latour B. 2007. "A Textbook Case Revisited: Knowledge as a Mode of Existence," [in:] The Handbook of Science and Technology Studies, eds. E. Hackett, O. Amsterdamska, M. Lynch, J. Wajcman, MIT Press, pp. 83-112.

/// Latour B. 2018. Aramis, oder die Liebe der Technik. Mit einem neuen Vorwort v. Bruno Latour und einem Nachwort v. Henning Schmidgen, Historische Wissensforschung, vol. 10, Mohr Siebeck.

/// Latour B., Woolgar S. 1986. Laboratory Life: The Construction of Scientific Facts, Princeton University Press.

/// Law J. 2008. After Method: Mess in Social Science Research, Routledge. 
/// Liniger S., Suter R. 2013. "Self-Fulfilling Prophecies: Zeitfiguren bei Nayler, Hobbes und Defoe," [in:] Dynamische Figuren: Gestalten der Zeit im Barock, eds. J. Lande, R. Schlögl, R. Suter, Rombach, pp. 209-240.

/// Luhmann N. 2000. The Reality of the Mass Media, Stanford University Press.

/// McIntyre L. 2018. Post-Truth, MIT Press.

/// McMillan S.L. 2017. Lies, Damned Lies and Alternative Facts: A Truth Seeker's Guide to Navigating Post-Truth Society, KC Editing.

/// Mannheim K. 1964. Wissenssoziologie, Luchterhand.

/// Mannheim K. 1965 [1929]. Ideologie und Utopie, 4th ed., Schulte-Bulmke.

/// Moore G.E., Ramsey F.P. 1927. "Facts and Propositions," Proceedings of the Aristotelian Society, vol. 7, pp. 153-206.

/// Nietzsche F. 2007 [1882]. The Gay Science. With a Prelude in German Rhymes and an Appendix of Songs, ed. Bernard Williams, Cambridge University Press.

/// Paravicini W. 2010. Die Wabrheit der Historiker, De Gruyter.

/// Pickering A. 1992. Science as Practice and Culture, University of Chicago Press.

/// Pickering A. 1995. The Mangle of Practice: Time, Agency, and Science, University of Chicago Press.

/// Pickering A. 2009. "The Politics of Theory: Producing Another World, with Some Thoughts on Latour," Journal of Cultural Economy, vol. 2(1), pp. 197-212, https://doi.org/10.1080/17530350903064204.

/// Pickering A., Guzik K., eds. 2008. The Mangle in Practice: Science, Society, and Becoming, Duke University Press.

/// Pörksen B. 2018. "Die neuen Wahrheitskriege," Zeitschrift für Medienwissenschaft, vol. 19(2), pp. 69-76, https://doi.org/10.14361/zfmw-2018-100209.

/// Reckwitz A. 2017. Die Gesellschaft der Singularitäten: Zum Strukturwandel der Moderne, Suhrkamp.

/// Regan M. 2017. “'Science Is Crucial to the Future' - March for Science Draws Thousands," https://www.pbs.org/newshour/science/march-forscience, accessed 7.05.2020. 
/// Rheinberger H. 1997. "Experimental Complexity in Biology: Some Epistemological and Historical Remarks," Philosophy of Science, vol. 64(4), pp. 245-254, https://doi.org/10.1086/392604.

/// Rheinberger H. 2001. Experimentalsysteme und epistemische Dinge: Eine Geschichte der Proteinsynthese im Reagenzglas, Wallstein.

/// Rose N. 1996a. "Identity, Genealogy, History," [in:] Questions of Cultural Identity, eds. S. Hall, P. Du Gay, Sage, pp. 128-150.

/// Rose N. 1996b. "The Death of the Social? Re-Figuring the Territory of Government," Economy and Society, vol. 25, pp. 327-356, https://doi. org/10.1080/03085149600000018.

/// Ruffing R. 2008. Michel Foucault, Fink.

/// Rüsen J. 2006. "Wissenschaft und Wahrheit: Anmerkungen zum kulturellen Anspruch rationalen Denkens," [in:] J. Rüsen, Kultur macht Sinn: Orientierung zwischen Gestern und Morgen, Böhlau, pp. 157-168.

/// Sarasin P. 2019. "Anything goes": Paul Feyerabend und die etwas andere Postmoderne, Geschichte der Gegenwart, https://doi.org/10.5167/uzh-182292.

/// Schlögl R. 2008. "Kommunikation und Vergesellschaftung unter Anwesenden: Formen des Sozialen und ihre Transformation in der Frühen Neuzeit," Geschichte und Gesellschaft, vol. 34, pp. 155-224, https://doi.org/10.13109/gege.2008.34.2.155.

/// Schmidt R. 2012. Soziologie der Praktiken: Konzeptionelle Studien und empirische Analysen, Suhrkamp.

/// Seemann M. 2017. "Digitaler Tribalismus und Fake News," ctrl+verlust, https://www.ctrl-verlust.net/digitaler-tribalismus-und-fake-news/, accessed 28.05.2020.

/// Shapin S. 1995. A Social History of Truth: Civility and Science in SeventeenthCentury England, University of Chicago Press, https://doi.org/10.7208/ chicago/9780226148847.001.0001.

/// Signori G., Rösinger A. 2014. Die Figur des Augenzengen: Geschichte und Wabrbeit im fächer- und epochenübergreifenden Vergleich, UVK.

/// Strawson P.F. 1949. “Truth,” Analysis, vol. 9, pp. 83-97, https://doi. org/10.1093/analys/9.6.83.

/// Taylor C. 1995. The Malaise of Modernity, House of Anansi Press. 
/// Trilling L. 1972. Sincerity and Authenticity, Harvard University Press.

/// Umbach M., Humphrey M. 2018. Authenticity: The Cultural History of a Political Concept, Palgrave Macmillan.

/// Wehler H. 1998. Die Herausforderung der Kulturgeschicbte, Beck.

/// Weingart P. 2017. “'Wahres Wissen” und demokratisch verfasste Gesellschaft," Aus Politik und Zeitgeschichte, vol. 67(13), pp. 11-16, https://www. bpb.de/apuz/245215/wahres-wissen-und-demokratisch-verfasste-gesellschaft, accessed 30.09.2020.

/// Wilber K. 2017. Trump and a Post-Truth World, Shambhala.

/// Willems H. 2009. “Zur Einführung: Theatralität als Ansatz, (Ent-)Theatralisierung als These," [in:] Die Theatralisierung der Gesellschaft, ed. H. Willems, vol. 1, VS Verlag für Sozialwissenschaften, pp. 13-56, https://doi. org/10.1007/978-3-531-91442-8_1.

/// Williams B. 2003. Wahrheit und Wabrhaftigkeit, Suhrkamp.

\section{/// Abstract}

Our truth culture has changed. Yet we are not living in a post-truth era but in a truth era - an observation of the ongoing debates shows a proliferation of invocations of truth. This paper argues that in order to grasp this transition, we should not refer to classical truth theories or common oppositions such as knowledge and belief, objectivity and subjectivity. Instead, we should focus on concrete practices in concrete situations: on "doing truth." This paper introduces the concept of a "praxeology of truth," which sets out to analyse truth by means of two parameters: "truth scenes" and "truth figures." In suggesting that to ask about truth is to pose the question of power, it follows Michel Foucault, but it regards the invocation of truth as a technique of identity politics and truth as a social operator.

Keywords:

fake news, political epistemology, post-truth, praxeology of truth, social disintegration

/// Bernhard Kleeberg - professor teaching the history of science at the Max Weber Centre for Advanced Cultural and Social Studies of the University of Erfurt in Germany. His current research focuses on the history of 
social psychology and the historical epistemology and praxeology of truth. $\mathrm{He}$ is editor-in-chief of the book series Historische Wissensforschung (Studies in the History of Knowledge) and co-editor of NTM - Zeitschrift für Geschichte der Wissenschaften, Technik. und Medizin (Journal of the History of Science, Technology and Medicine). He recently finished his book Standard of Living: History of a Concept (forthcoming in 2021). Among his most important publications are "Bad Habits and the Origins of Sociology" (2015, in Rethinking Order: Idioms of Stability and De-Stabilization, eds. Nicole Falkenhayner et al.); Ernst Mach und das Gedankenexperiment um 1900, special issue of Berichte zur Wissenschaftsgeschichte (2015); “Doing Truth'. Bausteine einer Praxeologie der Wahrheit" (2014, with Robert Suter, in Wabrheit. Zeitscbrift für Kulturphilosophie); Schlechte Angewohnbeiten (2012, ed.); Knowing God, Believing Nature, special issue of Science in Context (2007, co-ed. with Fernando Vidal); Theophysis. Ernst Haeckels monistische Philosophie des Naturganzen (2005).

ORCID: https://orcid.org/0000-0002-7299-2331

E-mail: bernhard.kleeberg@uni-erfurt.de 